\title{
TAMAN MINI INDONESIA INDAH SEBAGAI BAGIAN DARI FENOMENA TAMAN BUDAYA DUNIA
}

\author{
Anak Agung Ayu Wulandari \\ Jurusan Desain Interior, School of Design, BINUS University \\ Jl. KH. Syahdan No.9, Palmerah, Jakarta Barat 11480 \\ ayuwulan.indrajaya@gmail.com
}

\begin{abstract}
Cultural display in an open space or known as cultural parks appears rapidly as a worldwide phenomenon. From the European model which has a strong educational value, to the Asian parks which not only has educational function, but also has recreational purposes. So many types and characteristics of these parks, researches give them different names, thodse are Open-air museums, Ethnographic Theme Parks or even Theme Parks. Taman Mini Indonesia Indah as a part of this phenomenon was built first and foremost for educational purposes, therefore Taman Mini can be considered as an open-air museum. However, since Taman Mini also has recreational purposes, others can argue that Taman Mini is a theme park. Qualitative method will be used for this research, through observation to Taman Mini Indonesia Indah, followed by extensive literature review. With these data along with a table which points out the distinction between museum and theme parks. It can be concluded that Taman Mini is a Theme Park.
\end{abstract}

Keywords: Taman Mini Indonesia Indah, open-air museums, theme parks, cultural displays

\begin{abstract}
ABSTRAK
Sebuah ruang terbuka yang menampilkan budaya, atau taman budaya muncul sebagai fenomena dunia, mulai dari model Eropa yang menekankan pada fungsi edukasi sampai dengan model Asia yang selain menawarkan edukasi, juga menawarkan rekreasi. Begitu banyak model dan karakteristik taman budaya yang dinamakan museum terbuka, taman rekreasi etnografis atau taman rekreasi. Taman Mini Indonesia Indah sebagai bagian dari fenomena ini didirikan dengan tujuan awal untuk edukasi sehingga menjadikan Taman Mini sebagai museum terbuka (Open-air museum.) Namun karena juga berfungsi sebagai tempat rekreasi, muncul argumen lain bahwa Taman Mini adalah taman rekreasi. Metode kualitatif akan dilakukan dalam penelitian ini, melalui observasi langsung ke Taman Mini, ditunjang dengan studi literatur. Melalui data literatur dan tabel yang mengemukakan perbedaan mendasar antara museum dan taman rekreasi, dapat disimpulkan bahwa Taman Mini termasuk dalam klasifikasi taman rekreasi.
\end{abstract}

Kata kunci: Taman Mini Indonesia Indah, museum terbuka, taman rekreasi, tampilan budaya 


\section{PENDAHULUAN}

Seorang warga negara Indonesia, baik anak-anak maupun dewasa pastilah mengenal Taman Mini Indonesia Indah. Selain menjadi salah satu tujuan rekreasi bagi penduduk Jakarta, Taman Mini Indonesia Indah juga merupakan tujuan utama bagi wisatawan domestik dan internasional yang berkunjung ke Jakarta. Berlokasi di daerah timur Jakarta, Taman Mini didirikan atas inisiatif mendiang Ibu Negara, Ibu Tien Soeharto sebagai suatu wadah bagi generasi muda Indonesia untuk mengenal dan mempelejari berbagai suku, adat istiadat dan agama yang ada di Indonesia melalui berbagai fasilitas utama seperti anjungan daerah, museum, teater dan fasilitas penunjang seperti istana anak-anak, area outbound, dan lain-lain. Dengan mengusung semboyan Bhinneka Tunggal Ika; walaupun berbeda-beda tetapi tetap satu juga, sangatlah jelas bahwa Taman Mini didirikan dengan misi utama adalah pendidikan, yaitu untuk mengedukasi masyarakat, terutama generasi muda Indonesia terhadap keragaman budaya Indonesia, sehingga generasi muda Indonesia mengenal budaya satu sama lain.

Hitchcock (1998) menyebutkan Taman Mini sebagai museum terbuka (open-air museum). Masyarakat Indonesia pada umumnya lebih mengenal museum sebagai sebuah ruang tertutup untuk menyimpan artefak dan benda-benda bersejarah lainnya. Di Indonesia tidak banyak dikenal istilah museum terbuka padahal konsep museum terbuka ini sudah ada sejak lama. Museum sendiri mempunyai beberapa fungsi utama. Salah satu fungsi utama museum adalah edukasi dan fungsi ini merupakan alasan utama dari keberadaan museum (Hooper-Greenhill, 1994). Karena tujuan utama didirikannya Taman Mini ini adalah untuk pendidikan, maka sangat tepatlah apabila Taman Mini dikategorikan sebagai museum terbuka.

Selain Taman Mini Indonesia Indah, banyak sekali museum terbuka lainnya yang terdapat di berbagai negara di seluruh dunia, baik di Eropa maupun Asia. Walaupun menampilkan satu hal yang sama yaitu budaya, museum terbuka ini muncul dengan berbagai model dan karakteristik. Penulis dan peneliti memberi mereka nama-nama yang berbeda, seperti museum terbuka atau Open-air Museums (Hitchcock, 1998), Ethnographic Theme Parks (Stanley, 1998) dan Theme Parks (Hendry, 2000). Apabila diteliti lebih jauh mengenai berbagai jenis dan karakteristik dari museum terbuka ini, maka muncullah argumen lain bahwa Taman Mini Indonesia Indah tidaklah sesuai dengan kriteria museum, tetapi lebih kepada taman rekreasi (Theme Parks).

Dalam artikel ini akan dijelaskan mengenai sejarah museum terbuka, perbandingan museum dibandingkan dengan taman rekreasi dan akan disimpulkan apakah Taman Mini Indonesia Indah dapat dikategorikan sebagai museum terbuka ataukah taman rekreasi. Karena banyaknya sebutan terhadap fenomena menampilkan budaya (Cultural Displays) dalam sebuah ruang terbuka ini, maka untuk memudahkan pemahaman istilah Taman Budaya (Cultural Parks) akan digunakan sebelum pengklasifikasian antara museum terbuka dan taman rekreasi menjadi lebih jelas.

\section{METODE}

Penelitian dilakukan dengan menggunakan metode kualitatif, yaitu dengan observasi langsung ke Taman Mini Indonesia Indah untuk memperoleh data mengenai anjungan dan benda-benda budaya lainnya yang dipamerkan di Taman Mini. Perbandingan data antara Taman Mini dan taman-taman budaya lainnya, serta data sekunder lainnya mengenai taman budaya dunia lainnya akan diperoleh melalui studi literatur. 


\section{HASIL DAN PEMBAHASAN}

Fenomena menampilkan budaya dalam suatu ruang terbuka muncul hampir di seluruh belahan dunia, mulai dari Eropa sampai Asia. Taman budaya pertama didirikan pada tahun 1891 oleh Arthur Hazelius di Stockholm, Swedia dengan nama Skansen. Taman budaya ini memamerkan bangunan dan rumah-rumah pedesaan Swedia, yang dipindahkan dari lokasi aslinya dan didirikan kembali di Skansen. Ketika itu, Hazelius melihat perubahan besar-besaran terjadi pada masyarakat Swedia. Banyak masyarakat pedesaan yang bermigrasi ke kota atau bahkan ke negara lain, sehingga rumah tempat mereka tinggal dibiarkan terbengkalai dan ditinggal begitu saja. Membuat Hazelius berinisiatif untuk memindahkan dan melestarikan bangunan-bangunan tersebut.

Pada saat awal didirikan, Hazelius juga melengkapi Skansen dengan furnitur dan peralatanperalatan rumah tangga yang juga dikumpulkan dari pedesaan-pedesaan Swedia, serta boneka-boneka manusia, sehingga bangunan tersebut terlihat hidup. Namun pada tahun 1926, boneka-boneka tersebut diganti oleh contoh-contoh hidup, yang berasal dari masyarakat pedesaan Swedia yang sudah semakin terpinggirkan. Mereka melakukan kegiatan, berpakaian dan berinteraksi seperti layaknya penghuni asli dari bangunan dan rumah-rumah tradisional tersebut. Hal ini dilakukan karena ternyata yang menghilang tidak hanya bangunan dan arsitektur pedesaan Swedia, tetapi juga budaya tradisional yang diasosiasikan dengan bangunan-bangunan tersebut (Stanley, 1998). Perkembangan Skansen begitu pesatnya, saat ini Skansen dibagi menjadi beberapa area utama, yaitu area perumahan pedesaan, area perkotaan abad ke-19, area bangunan-bangunan lain serta area taman.

Setelah Skansen, taman budaya serupa didirikan di berbagai daerah di Eropa, seperti Arnhem di Belanda pada tahun 1911, St. Fagans di Wales pada tahun 1949 dan Cultra di Ulster pada tahun 1958 (Hitchcock, 1998). Karena sangat kuatnya fungsi pendidikan dan preservasi pada taman budaya model Eropa ini, maka sangatlah wajar apabila taman-taman budaya ini disebut sebagai museum terbuka.

Apabila di Eropa terdapat Skansen, Arnhem, St. Fagans dan Cultra, negara-negara Asia Pasifik juga memiliki beberapa versi lain dari taman budaya ini, seperti: Canadian World, Reoma World, Swiss Villag, Parque Espana dan lain sebagainya di Jepang, Splendid China, Window of the World dan China Folk Culture Village (FCV) di China, Taiwan Aboriginal Culture Park (TACP) dan Formosan Aboriginal Cultural Village (FACV) di Taiwan, Polynesian Cultural Centre (PCC) di Hawaii, Taman Mini Indonesia Indah di Indonesia serta taman-taman lainnya di Malaysia dan Thailand. Stanley (1998) dan Hendry (2000) memberikan deskripsi mendetail mengenai taman-taman budaya ini. Stanley, meneliti lebih jauh mengenai taman yang berada di negara-negara Asia Pasifik dan menyebut mereka sebagai Ethnographic Theme Parks sedangkan Hendry menekankan pada taman-taman budaya di Jepang.

Polynesian Cultural Center (PCC), merupakan taman budaya pertama yang didirikan di Hawai yang kemudian diikuti menjamurnya taman budaya di kepulauan Fiji. Berbeda dengan museum terbuka di Eropa, Ross (dikutip oleh Stanley, 1998) menekankan ada dua hal penting dalam taman budaya semacam ini, yaitu arsitektur dan pertunjukan. Kedua hal ini akan ditemui hampir di semua taman budaya di Asia Pasifik. Di PCC otentisitas arsitektural menjadi pertanyaan utama, seperti material yang digunakan untuk konstruksi bangunan misalnya, banyak material yang sudah diganti menjadi material yang lebih modern. Namun lain halnya dengan otentisitas pertunjukan-pertunjukan yang diadakan. Pertunjukan ini merupakan kebudayaan asli suku-suku Fiji yang sudah mulai ditinggalkan. Dengan adanya PCC ini, kebudayaan ini menjadi seperti hidup kembali dan kembali dipelajari oleh generasi muda untuk dipertontonkan kepada pengunjung-pengunjung PCC. 
Seperti tidak mau ketinggalan, Cina juga ikut mendirikan taman budaya serupa, tidak hanya 1 tetapi sekaligus 3 taman yang didirikan dengan selang waktu yang tidak terlalu jauh. Semuanya berlokasi di kota Shenzen, Splendid China didirikan pada tahun 1989, China Folk Culture Villages pada tahun 1991 dan Window of the World pada tahun 1995. Ketiga taman ini menampilkan budaya yang berbeda. Dalam area seluas 75 are saja, Splendid China dapat menampilkan 48 pemandangan alam kebanggaan Cina, 15 bangunan bersejarah Cina dan juga tidak ketinggalan The Imperial Palace atau istana kerajaan Cina yang begitu terkenal. Tentu saja semuanya hanya dalam bentuk miniatur. Dilengkap dengan 65.000 figurin keramik manusia yang dipasang di sekitar miniatur bangunanbangunan tersebut, Splendid China mempromosikan taman budayanya sebagai The World's Largest Miniature Spot (Stanley, 1998).

China Folk Culture Villages (CFCV) menawarkan tampilan budaya yang lebih menarik daripada hanya sekedar miniatur dan figurin keramik seperti di Splendid China. Mengelilingi sebuah danau, terdapat sekitar 20 arsitektur tradisional Cina milik etnis-etnis minor pilihan. Tidak ada usaha untuk membuat arsitektur ini otentik, tetapi dibangun berdasarkan keadaannya sekarang, seperti penambahan AC, perubahan fungsi-fungsi ruang dan lain-lain. Namun-namun rumah-rumah tradisional ini dihuni oleh penduduk etnis minor itu sendiri, sehingga pengunjung dapat berinteraksi langsung dengan mereka, pertunjukan-pertunjukan yang diadakan secara rutinpun dilakukan oleh mereka. Hal ini menarik karena etnis-etnis minor ini yang langsung melakukan interpretasi terhadap budaya mereka sendiri dan bukan hanya sekedar menjadi objek pameran.

Stanley (1998) menekankan kontroversi yang terjadi pada kedua taman budaya ini adalah, bagaimana pemilihan, baik pemandangan, tempat bersejarah ataupun etnis-etnis minor itu dilakukan. Dari apa yang dikatakan oleh Ma (dikutip dari Stanley, 1998) Splendid China, dibangun untuk memperlihatkan keindahan pemandangan alam Cina, kemegahan sejarahnya serta keanekragamaan budayanya dalam waktu yang singkat. Dari pernyataan ini dapat disimpulkan bahwa Splendid China lebih ditujukan kepada pengunjung-pengunjung asing. Apabila pengunjung tidak memiliki pengetahuan mengenai sejarah Cina, maka mungkin objek-objek yang dipamerkan menjadi asing dan dan tidak dapat dimengerti. Seperti pemilihan etnis minor, dari semua etnis minor yang ada, yang mana yang harus ditampilkan? Apakah ada unsur politis dibalik pemilihan etnis-etnis minor ini?

Seperti telah dijelaskan sebelumnya bahwa arsitektur dan pertunjukan memegang peranan penting pada PCC dan taman-taman budaya di Cina. Arsitektur yang berupa replika, bahkan miniatur yang tidak menekankan pada otentisitas dan juga pertunjukan-pertunjukan budaya yang menawarkan kesenangan dan hiburan. Unsur edukasi dirasakan sangat kurang pada taman-taman ini dan lebih menekankan pada fungsi-fungsi hiburan dan rekreasi, sehingga PCC dan taman-taman budaya di Asia dikategorikan sebagai Ethnographic Theme Parks (Stanley, 1998).

Lain halnya dengan PCC, Splendid China dan CFCV yang memperkenalkan keanekaragaman budaya bangsa sendiri baik melalui miniatur, arsitektur maupun pertunjukan-pertunjukan budaya, Jepang memilih untuk mengambil tema-tema budaya asing pada taman budayanya. Dari 28 taman budaya yang ada di Jepang, beberapa memilih untuk menampilkan periodisasi sejarah Jepang, beberapa lainnya menampilkan tema-tema sinematografi. Namun kelompok yang paling banyak bukanlah taman budaya yang menampilkan budaya Jepang, tetapi justru mengambil tema budaya negara asing, lebih dikenal sebagai gaikoku mura atau pedesaan negara asing (Hendry, 2000). Tamantaman ini merepresentasikan kebudayaan negara-negara barat, seperti Canadian World (Canada), Glucks Konigreich (Jerman), Huis Ten Bosch (Belanda), Parque Espana (Spanyol) dan Roshia-mura (Rusia) dan taman budaya lain yang menampilkan rumah tradisional, tempat ibadah, pakaian dan artefak-artefak budaya dari berbagai negara asing. Hendry (1997) juga menjelaskan bahwa ledakan taman budaya yang mengangkat teman sejarah dan budaya asing di Jepang terjadi pada tahun 1990an pada periode 'internasionalisasi', dimana masyarakat Jepang dihimbau untuk memperluas wawasan mereka dengan mempelajari bahasa asing, menonton film asing serta melakukan perjalanan ke negara- 
negara asing. Namun karena keterbatasan waktu dan dana yang dimiliki, gaikoku mura menjadi pilihan.

Kesamaan dari taman-taman budaya Jepang ini adalah mereka menawarkan fantasi. Taman budaya Jerman, Glucks Konigreich, menggunakan penulis Jerman terkenal Grimm bersaudara sebagai tema utama dari taman tersebut, seperti pembagian zona menjadi desa Grimm, hutan Grimm dan lain sebagainya. Cerita-cerita karangan Grimm bersaudara juga ikut serta dijadikan tema pendukung. Sedangkan Canadian World, mengambil tema cerita Anne of Green Gables, lengkap dengan replika rumah dan sekolah tokoh Anne dalam cerita tersebut, serta karakter Anne yang dapat ditemui di sekitar taman dan diajak berfoto bersama. Selain menawarkan sejarah dan budaya, taman-taman budaya ini juga menjual berbagai makanan, minuman dan cinderamata yang berasal dari negaranegara asing tersebut, bahkan beberapa dengan pesan bahwa barang-barang ini tidak akan dapat ditemukan di tempat lain di Jepang.

Yang menarik dari taman-taman ini adalah otentisitas dan originalitas bukanlah sesuatu yang hal menjadi perhatian utama. Sudah jelas semua bangunan adalah replika, selain itu makanan dan minuman juga tidaklah selalu otentik, seperti yang dijual di Parque Espana misalnya. Manajemen mengatakan bahwa walaupun berasal dari Spanyol, rasa makanan dan minuman tersebut disesuaikan lidah masyarakat Jepang, begitu pula dengan seniman-seniman yang tampil pada pertunjukanpertunjukan rutin di taman budaya tersebut. Apabila Parque Espana memperkerjakan lebih dari 100 seniman asli Spanyol, pertunjukan-pertunjukan di Glucks Konigreich, ditampilkan oleh penari dan pemain musik yang berasal dari Rumania, Cekoslovakia dan Hungaria, dengan alasan manajemen taman tidak sanggup membayar seniman-seniman asli Jerman.

Setelah diuraikan mengenai taman budaya di dunia, berikut akan didiskusikan mengenai Taman Mini Indonesia Indah (Taman Mini), sebagai contoh taman budaya yang ada di Indonesia. Seperti sudah diketahui oleh khalayak umum, ide didirikannya Taman Mini pertama kali dilontarkan oleh Ibu Tien Soeharto. Melihat keragaman etnis, suku dan agama yang ada di Indonesia, beliau percaya bahwa untuk membangkitkan dan membangun nasionalisme yang lebih kuat, bangsa Indonesia harus belajar mengenal satu sama lain, baik antar etnis, suku dan agama, sehingga konflik dan ketegangan antar etnis, suku dan agama dapat dihindari dan Taman Mini dicanangkan oleh sebagai salau satu wadah untuk mencapai harapan ini.

Pemberton (1994) mengutip bahwa mendiang Ibu Tien terinsipirasi untuk mendirikan Taman Mini setelah kunjungannya ke Disneyland. Apabila melihat bangunan istana anak-anak yang terdapat di Taman Mini, mengadaptasi bentuk istana Ludwig of Bavaria di Neuschwanstein, Jerman, dimana bangunan ini juga menjadi logo dari perusahaan Disney. Maka sangat besar kemungkinan apabila ide didirkannya Taman Mini memang berasal dari Disneyland (Stanley, 1998).

Projek pengerjaan Taman Mini dimulai pada tahun 1971. Empat tahun kemudian, pada tahun 1975, Taman Mini Indonesia Indah dibuka untuk pertama kalinya. Dibangun di lahan seluas 425 are, sebuah danau buatan dengan miniatur dari kepulauan Indonesia menjadi pusat dari Taman Mini. Mengelilingi danau, 27 anjungan daerah didirikan untuk menampilkan 27 propinsi yang ada di Indonesia. Di dalam anjungan tersebut, dapat ditemukan berbagai informasi mengenai propinsi tersebut, manekin dengan busana tradisional, artefak-artefak budaya, cinderamata dan lain-lain. Seperti taman budaya Asia Pasifik lainnya yang mengutamakan arsitektur dan pertunjukan sebagai fokus dari taman budayanya, setiap anjungan di Taman Mini juga dilengkapi dengan teater kecil baik itu teater terbuka ataupun tertutup. Selain anjungan daerah, juga terdapat berbagai tempat ibadah, ruang serba guna, taman burung, taman bunga, aquarium, teater IMAX, istana anak-anak dan 20 museum. Kereta gantung juga disediakan bagi para pengunjung untuk menikmati kompleks Taman Mini dari pandangan yang lebih tinggi. Pada perkembangannya saat ini, Taman Mini telah mengubah salah satu anjungan, yaitu anjungan Timor Timur menjadi Museum Timor Timur, menambahkan jumlah anjungan daerah, sesuai dengan perubahan jumlah propinsi di Indonesia, menambah tempat 
ibadah dan beberapa fasilitas lainnya seperti penginapan, kolam renang, area outbound anak-anak dan lain-lain.

Sejak pertama kali diresmikan, bahkan jauh sebelum diresmikan, Taman Mini banyak menuai kritik dan kontroversi. 27 anjungan daerah didirikan, bukan berdasarkan grup etnis, tetapi berdasarkan apa yang disebut dengan kebudayaan daerah (Picard, 1997). Walaupun dalam satu propinsi mungkin terdapat lebih dari satu grup etnis, di Taman Mini berbagai group etnis ini ditampilkan berdasarkan pembagian wilayah administratif, yaitu propinsi. Seperti yang dikemukakan oleh Hitchcock (1998), Taman Mini bukanlah museum mengenai orang-orang dan kebudayaan Indonesia, tetapi lebih kepada museum mengenai propinsi-propinsi di Indonesia. Taman Mini sendiri menganggap ini adalah cara yang paling adil dan cocok dalam menampilkan berbagai budaya di Indonesia, yaitu dengan mendirikan rumah tradisional untuk merepresentasikan setiap propinsi dan memamerkan objek-objek dan artefak kebudayaan dari grup etnis lainnya di dalam rumah tradisional tersebut.

Kontroversi lain adalah gaya arsitektur ruang serba guna yang ada di Taman Mini mengadopsi gaya Jawa Tengah dan diberi nama Pendopo Agung Sasono Utomo, yang merupakan nama Jawa Tengah dan bukan nama Indonesia. Begitu juga dengan salah satu museum di Taman Mini, yaitu Museum Indonesia yang mengadopsi gaya arsitektur Bali. Museum ini memuat berbagai objek dari berbagai wilayah dan grup etnis di Indonesia. Pameran utama dari museum ini adalah diorama upacara pernikahan tradisional Solo yang dihadiri oleh tamu-tamu yang menggunakan pakaian tradisional dari berbagai daerah di Indonesia. Diorama ini seharusnya merepresentasikan ke-Bhinneka Tunggal Ika-an Indonesia, namun mereka menggunakan manekin pengantin Solo, dengan detail yang sangat indah, berkebalikan dengan beberapa tamu yang menggunakan busana terbuat dari rumput dan hiasan kepala terbuat dari bulu-bulu burung. Menurut Pemberton (1994), para kaum elit Jawa Tengah yang tinggal di Jakarta merupakan suporter utama dari Taman Mini, termasuk Presiden Soeharto dan istrinya Ibu Tien Soeharto. Hal ini membuktikan bahwa pemilihan budaya yang direpresentasikan di Taman Mini tidak merata melainkan didominasi oleh etnis grup tertentu.

Pemberton juga menambahkan, Taman Mini telah menjadi salah satu tempat yang harus dikunjungi oleh anak-anak Indonesia. Salah satu buku terbitan Departemen Pendidikan dan Kebudayaan menggambarkan seorang siswa mengadakan kunjungan ke Taman Mini. Di Taman Mini para siswa dapat melihat berbagai objek budaya yang sebelumnya hanya dapat dilihat di foto sebelumnya, seperti mini Borobudur misalnya atau Rumah Gadang dan lain sebagainya. Hal ini menunjukan, walaupun menuai berbagai kontroversi, Taman Mini sudah memiliki tempat tersediri bagi masyarakat Indonesia.

Hitchcock dkk (1997) mendiskusikan mengenai China Folk Culture Village di Shenzen, China dan Taman Mini Indonesia Indah di Jakarta serta membandingkannya dengan museum terbuka model Eropa. Hitchcock menegaskan bahwa walaupun penampilan taman-taman budaya Asia ini serupa dengan yang ada di Eropa, konsep dan filosofi dasar dari taman ini berbeda.

Museum terbuka di Eropa mempunyai fungsi preservasi yang sangat kuat, seperti Skansen didirikan untuk menyelamatkan dan melindungi rumah dan bangunan tradisional Swedia yang sudah tidak terawat, semakin sedikit dan hampir punah. Bangunan yang digunakan adalah bangunan asli yang dikumpulkan dari berbagai daerah pedesaan di Swedia dan didirikan kembali di Skansen, sementara pada taman budaya Asia, bangunan-bangunan tradisional yang ada memang didirikan khusus untuk taman tersebut dan bukanlah bangunan asli yang diambil dari daerah asal bangunan tersebut. Dalam hal otentisitas, bangunan-bangunan pada museum terbuka Eropa lebih otentik daripada taman budaya di Asia

Lebih jauh mengenai Taman Mini, anjungan daerah, bangunan lainnya dan objek-objek budaya yang ada di Taman Mini semuanya adalah baru dan dibuat khusus untuk Taman Mini. Begitu pula dengan koleksi di dalam Museum Indonesia, pada saat pertama kali diresmikan pada tahun 
1980an, semua objek pamerannya benda-benda yang baru. Berbeda dengan konsep museum yang seharusnya menyimpan benda-benda asli dan bersejarah. Ketika ditanya mengenai apakah Museum Indonesia memang benar-benar sebuah museum karena koleksinya semua adalah objek-objek yang baru, mendiang Ibu Tien Soeharto mengatakan bahwa kita dapat menyebutnya museum sekarang, karena suatu saat nanti semua benda yang ada di dalamnya akan menjadi benda-benda antik (Pemberton, 1994).

Apabila museum terbuka di Eropa didirikan dengan fungsi edukasi dan preservasi yang sangat kuat, lain halnya dengan taman-taman budaya di Asia. Taman di Asia, terutama Taman Mini dan taman-taman budaya di Asia Pasifik lainnya didirikan untuk merepresentasikan budaya dan suku bangsa yang dimiliki. Beragam etnis dan suku, ditampilkan melalui rumah adat, pertunjukanpertunjukan seni dan budaya serta berbagai festival budaya dengan berbagai tujuan. Tama Mini bertujuan untuk memperkenalkan keragaman etnis dan suku bangsa, sehingga pengunjung dari berbagai suku dan daerah dapat saling mengenal satu sama lain, atau dengan kata lain, untuk membangun dan membangkitkan nasionalisme, sedangkan Splendid China, CFCV didirikan untuk memperkenalkan keanekaragaman pemandangan, bangunan-bangunan historis dan etnis-etnis minor di Cina kepada pengunjung asing.

Namun, kita tidak dapat mengeneralisasikan semua taman Asia merepresentasikan keanekaragaman etnis dan suku bangsa, karena taman budaya di Jepang berbeda. Jepang memilih untuk mengadopsi tema budaya barat untuk taman budaya mereka, sehingga sangat jelas bahwa misi mereka bukanlah untuk preservasi ataupun untuk membangun nasionalisme, tetapi untuk memperkenalkan budaya asing kepada masyarakat Jepang, serta mempunyai fungsi komersil yaitu untuk menjual barang-barang produksi luar negeri. Apabila taman budaya di Jepang didirikan sematamana hanya untuk kesenangan dan rekreasi, tanpa adanya sedikitpun fungsi preservasi dan edukasi, maka apakah taman budaya Jepang dapat dikategorikan sebagai taman rekreasi?

Marriot Corporations mendefinisikan taman rekreasi (Theme Park) sebagai kompleks hiburan keluarga yang mengacu kepada tema atau daerah historis tertentu dengan mengkombinasikan penggunaan kostum, arsitektur, hiburan dan cinderamata untuk mempromosikan nuansa dan atmosfer fantasi (dikutip dari Boniface, 1994). Theme Park atau taman rekreasi adalah fantasi atau yang Boniface sebutkan dari asli menjadi tiruan hingga sepenuhnya tiruan. Apabila keaslian menjadi tolak ukur dari sebuah taman budaya, lalu apakah Taman Mini yang menampilkan objek-objek yang tidak asli merupakan taman rekreasi?. Hendry (2000) mendiskusikan lebih jauh bagaimana museum dan taman rekreasi diklasifikasikan. Tabel 1 menjelaskan perbedaan antara taman rekreasi dengan museum.

Tabel 1 Klasifikasi Taman Rekreasi dan Museum

\begin{tabular}{lll}
\hline & Taman Rekreasi & Museum \\
\hline Dasar pendirian & Komersil & Filantropik, untuk masyarakat \\
Tujuan & Kesenangan dan hiburan & Preservasi dan studi \\
Isi & Dibangun & Dikumpulkan \\
Otentisitas & Tidak penting & Objek asli \\
\hline
\end{tabular}

Lebih jauh, Hendry menunjukkan bahwa klasifikasi ini belumlah sempurna, karena museum pada saat ini tidak hanya menawarkan edukasi dan preservasi semata, tetapi juga menawarkan kesenangan dan hiburan. Selain untuk menghindari kebosanan, terutama untuk pengunjung anak-anak dapat belajar di dalam museum melalui cara yang lebih menyenangkan. Hal ini tentu saja juga akan meningkatkan jumlah pengunjung. Taman-taman rekreasi Jepang, banyak yang menerapkan hal ini, yaitu mengkombinasikan antara edukasi dan hiburan, walaupun sebagian besar mempunyai fungsi hiburan dan komersil, tetapi beberapa juga mempunya fungsi edukasi. 
Lalu bagaimana dengan Taman Mini? Apakah bisa disimpulkan bahwa Taman Mini adalah museum terbuka (Open-air Museum) ataukah taman rekreasi (Theme Parks). Melalui Tabel 1, dapat didiskusikan lebih jauh mengenai pengklasifikasian Taman Mini. Bila dilihat dari dasar pendirian, Taman Mini didirikan bukan atas dasar komersil, melainkan atas ide dari mendiang Ibu Tien Soeharto yang menginginkan bangsa Indonesia saling mengenal satu sama lain, yang walaupun berbeda namun tetap satu. Taman Mini juga diharapakan dapat membangun dan meningkatkan nasionalisme bangsa Indonesia. Sehingga dapat dikategorikan bahwa Taman Mini didirikan untuk masyarakat umum dan juga untuk filantropik.

Dengan dasar pendirian tersebut, sudah sangat jelas bahwa tujuan awal didirikan Taman Mini adalah untuk edukasi dan pelestarian budaya, namun ini merupakan merupakan visi dan misi dari Taman Mini. Apabila diamati pengunjung yang datang sebagian besar dari mereka datang untuk berekreasi dan berpiknik, dan bukan untuk studi. Ditambah lagi dengan adanya fasilitas-fasilitas tambahan yang didirikan beberapa tahun terakhir, seperti kolam renang dan area outbound anak-anak, dimana tujuan dari fasilitas tersebut sudah sangat jelas bukanlah untuk studi dan pelestarian budaya melainkan untuk rekreasi. Hal ini menyebabkan tujuan utama dari Taman Mini yang sudah dicanangkan sebelumnya menjadi bergeser.

Dilihat dari isinya, memang tidak seperti museum terbuka di Eropa yang mengambil bangunan dari tempat aslinya, semua bangunan yang ada di Taman Mini dibangun khusus untuk dipamerkan di Taman Mini. Begitu pula dengan objek-objek budaya yang ada di Taman Mini. Seperti yang telah dijelaskan sebelumnya, objek-objek pamer yang ada di Museum Indonesia misalnya, semua objek budaya yang dipamerkan adalah benda-benda baru yang dibuat khusus untuk museum tersebut. Melihat dari isinya yang dibangun khusus untuk Taman Mini, dapat disimpulkan bahwa otensititas tidak menjadi sesuatu hal yang penting, karena yang ditampilkan di Taman Mini sebagian besar bukanlah objek aslinya, baik itu anjungan daerah maupun objek-objek budaya lainnya.

\section{SIMPULAN}

Pada bagian Pembahasan, telah didiskusikan dengan lebih mendalam mengenai taman budaya di Eropa dan di Asia, mulai dari taman budaya Eropa, seperti Skansen yang mempunyai fungsi preservasi dan edukasi yang sangat jelas seperti layaknya sebuah museum, sehingga lebih dikenal dengan sebutan museum terbuka sampai kepada taman budaya Asia yang mempunya model dan karakteristik lebih beragam. Taman-taman budaya di Jepang banyak mengambil tema budaya barat, mempunyai tujuan yang lebih komersil. Selain untuk memperkenalkan budaya barat kepada masyarakat Jepang juga berfungsi untuk menjual produk-produk luar negeri, dengan pesan bahwa produk tersebut tidak dijual di tempat lain di Jepang. Taman-taman ini berusaha menciptakan fantasi sehingga otentisitas dan keaslian dari budaya yang ingin ditampilkan sudah tidak menjadi perhatian utama lagi. Kesenangan dan hiburan lebih banyak ditawarkan dibandingkan dengan edukasi. Sehingga taman-taman Jepang ini akan lebih sesuai bila dikategorikan sebagai taman rekreasi.

Lain lagi halnya dengan taman budaya di Cina, Splendid China dan CFCV misalnya di Shenzen, Cina. Taman ini berusaha merepresentasikan keanekaragaman etnis dan suku bangsa yang dimiliki oleh bangsa Cina. Serupa dengan Splendid China, Taman Mini Indonesia Indah juga didirikan untuk merepresentasikan keanekaragaman etnis dan suku bangsa, sehingga bangsa Indonesia saling mengenal satu sama lain. Beberapa peneliti menyebutkan Taman Mini sebagai museum terbuka, namun ada argumen lainnya bahwa Taman Mini adalah taman rekreasi. Lalu apakah Taman Mini dapat diklasifikasikan sebagai museum terbuka atau taman rekreasi? 
Melalui pengklasifikasian yang sudah dikemukakan oleh Hendry (2000) dan diteliti dari sisi dasar pendirian, tujuan, isi dan otentisitasnya, dapat disimpulkan bahwa Taman Mini termasuk dalam kategori taman rekreasi. Namun tentu saja kesimpulan ini tidaklah mutlak sepenuhnya.

Seperti telah dijelaskan juga bahwa untuk menarik peminat pengunjung, museum sekarang ini tidak hanya fokus pada fungsi edukasi tetapi juga untuk rekreasi. Tidak jarang museum memadukan antara fungsi edukasi (education) dan hiburan (entertainment) menjadi sebuah konsep postmodern: edutainment. Walaupun begitu tetap saja pemisahan antara fungsi edukasi dan rekreasi pada museum dan taman rekreasi di negara barat selalu sangat jelas (Hendry, 2000). Museum didirikan untuk fungsi edukasi; mengumpulkan, mempelajari dan mepreservasi objek. Skansen, sebagai museum terbuka juga mempunyai tujuan edukasi, walaupun juga disediakan fasilitas lain seperti café, restoran dan teater terbuka, fasilitas-fasilitas ini disediakan hanya sebagai fasilitas penunjang, untuk mendukung fungsi edukasi dari museum tersebut.

Sedangkan di Asia, pemisahan konsep antara edukasi dan rekreasi sangat tidak jelas, dimana sudah dikemukakan juga bahwa taman budaya Asia Pasifik berputar pada dua hal yaitu, arsitektur dan pertunjukan. Arsitektur mempunyai fungsi edukasi, walaupun bukan sepenuhnya arsitektur yang otentik dan pertunjukan mempunyai fungsi hiburan. Akan sangat disayangkan apabila taman-taman rekreasi di Jepang dikatakan hanya mempunya fungsi rekreasi, padahal di dalamnya juga terdapat museum dengan koleksi benda-benda yang mempunyai nilai sejarah. Sama halnya dengan Taman Mini. Sangat disayangkan apabila Taman Mini hanya disebut sebagai taman rekreasi semata, karena selain mempunya nilai-nilai rekreasi, Taman Mini juga mempunyai nilai edukasi yang luar biasa besarnya.

Apakah dengan ini dapat disimpulkan bahwa Taman Mini adalah taman rekreasi ataupun museum terbuka yang mengadopsi fungsi edukasi dan rekreasi (edutainment) secara sekaligus. Dimana kedua fungsi ini membaur menjadi suatu konsep yang tidak terpisahkan, sehingga pengunjung yang datang dapat berekreasi dan secara tidak sadar mereka juga dapat belajar mengenai budaya Indonesia? Penelitian lebih lanjut perlu dilakukan untuk mengetahui mengenai konsep edutainment secara lebih mendalam. Disneyland merupakan salah satu taman rekreasi yang merintis konsep edutainment, dan karena Ibu Tien Soeharto terinspirasi untuk mendirikan Taman Mini setelah kunjungannya ke Disneyland, apakah menjadikan Taman Mini juga mengadopsi konsep ini? Wawancara lebih mendalam perlu dilakukan terhadap manajemen Taman Mini, bagaimanakah persepsi mereka terhadap konsep ini.

\section{DAFTAR PUSTAKA}

Boniface, P. (1994). Theme Park Britain: Who benefits and who loses. Dalam J. M. Fladmark (ed.), Cultural Tourism. Aberdeen: Robert Gordon University.

Hendry, J. (2000). The orient strike back: A global views of cultural displays. Oxford: Berg.

Hitchcock, M. (1998). Tourism, Taman Mini and national identity. Indonesia and the Malay World, 26(75), 124-135.

Hitchcock, M., Stanley, N., \& Siu, K. C. (1997). The South-East Asian Living Museum and its Antecedents. Dalam S. Abram, dkk. (eds.), Tourists and tourism: Identifying with people and places. Oxford: Berg. 
Hooper-Greenhill, E. (1994). Museum education. Dalam E. Hopper-Greenhill (ed.), The educational role of the museum. London: Routledge.

Pemberton, J. (1994). On the subject of Java. New York: Cornell University Press.

Picard, M. (1993). Cultural tourism in Bali: National integration and regional differentiation. Dalam M. Hitchcock, dkk. (eds.), Tourism in South-East Asia. London: Routledge.

Stanley, N. (1998). Being Ourselves for You: the Global Display of Cultures. London: Middlesex University Press.

Taman Mini Indonesia Indah Guidebook. (1996). Pesona Wisata Budaya Taman Mini Indonesia Indah. Jakarta: Taman Mini Indonesia Indah. 